\title{
Local resources, foreign influences, value creation, tradition and modernity. The case of a Local Agro-food System in Jämtland, Sweden
}

\author{
Paulina Rytkönen \\ Department of Natural Sciences, Environment and Technology. Södertörn University. \\ Alfred Nobels Allé 7, 14189 Huddinge, Sweden. \\ e-mail: paulina.rytkonen@sh.se
}

Submitted: 14 July 2015. Accepted: 10 November 2015

\begin{abstract}
During the 1980's collective action was initiated with the purpose of saving the remnants of traditional livestock farming in Jämtland. This led to the articulation of a local agro-food system (LAFS) that managed to commercialize important elements of traditional agriculture by adding elements of modernity. Farm diversification was an important strategy that led to the forward integration of farms that includes the start of small scale farm dairies, farm cafes, direct sales, at the farm, through markets and other local channels, B\&Bs and outdoor tourism operations. In the mentioned process, foreign knowledge and experience led to the opening of a new market for traditional products. This case shows that the localization and appropriation of foreign elements can be a fruitful strategy to promote territorial development in regions like Jämtland. This article highlights how a LAFS was articulated within the frame of the birth of a new industry, composed by small, semi-artisan dairy firms and which institutional side effects that this experience has led to.
\end{abstract}

KEYWORDS: Localization; territorial development; territorial governance; farm diversification; rural development; farm dairies; new rurality.

Citation / Cómo citar este artículo: Rytkönen, Paulina (2016) "Local resources, foreign influences, value creation, tradition and modernity. The case of a Local Agro-food System in Jämtland, Sweden". Culture \& History Digital Journal, 5 (1): e009. doi: http://dx.doi.org/10.3989/chdj.2016.009.

RESUMEN: Recursos locales, influencias extranjeras, creación de valor, tradición y modernidad. El caso de un Sistema Agroalimentario Local en Jämtland, Suecia.- Durante la década de los 80, un proceso de acción colectiva se inició con el propósito de salvar los restos de la ganadería tradicional en Jämtland. Esto resultó en la creación de un sistema agroalimentario local que logró comercializar elementos importantes de la agricultura tradicional, añadiendo elementos de modernidad. La diversificación de las fincas fue la estrategia más importante, dentro de la cual se promovió la creación de un sector de pequeñas industrias lácteas en las fincas, cafés rurales y asimismo la venta directa a los consumidores en dichas fincas, en mercados y otros canales de comercialización, servicios de alojamiento y desayuno y operaciones turísticas al aire libre. En este proceso, conocimiento y experiencias extranjeras jugaron un papel clave en la apertura de un nuevo mercado para los productos lácteos tradicionales. Este caso demuestra que la localización y la apropiación de elementos extranjeros puede ser una estrategia fructífera para promover el desarrollo territorial en regiones como Jämtland. Este artículo pone de relieve cómo un sistema agroalimentario local se articula en el marco del nacimiento de una nueva industria compuesta por pequeñas empresas lácteas, de carácter semi-artesanal. También se discuten los efectos institucionales secundarios que fueron originados por esta experiencia.

PALABRAS CLAVE: Localización; desarrollo territorial; gobernanza territorial; diversificación de granjas; desarrollo rural; industrias lácteas rurales; nueva ruralidad.

Copyright: (C) 2016 CSIC. This is an open-access article distributed under the terms of the Creative Commons Attribution License (CC BY) Spain 3.0. 


\section{INTRODUCTION ${ }^{1}$}

The revival of the farm dairy sector in Sweden started out in the late 1970's as a project to save goat farming in the Northern inland province of Jämtland. Over a period of 40 years, the farm dairy sector has evolved into a small scale artisan industry that blends traditional products, landscape features and modern technologies in the process of creating income opportunities in one of Sweden's most rural and remote counties.

The farm dairy sector is composed by traditional goat farms; mixed farms with landrace cows and goats; and regular conventional milk farms with high yielding cow races which have been forward integrated by starting up a small artisan dairy that is often diversified adding a small coffee shop or restaurant, a B\&B and by offering tourism services such as hunting, fishing and/or a museum experience of how real life could be in the past (Rytkönen, et al., 2013). The income is generated by the sales of dairy products and by addressing the rural romanticism that always surrounded Swedish transhumance and traditional agriculture (Eriksson, 2013: 38-46).

The farm dairy sector emerged when local and regional forces initiated a collective action process to preserve and develop the remaining goat farms in the county. These initial investments ended up with the establishment of an infrastructure that sustained an innovation process in which a new type of joint marketing organization was developed, a new market was opened up, institutional barriers were forced and new products were developed (Rytkönen, et al., 2013). Most farm dairy owners in the sample claim that they are not primarily driven by economic interests, but still their livelihoods is achieved through farm dairying, therefore analyzing economic aspects of their experience is justified. According to the informants, their desire to reconnect with nature is at the top of their priorities, some strive to maintain a tradition by keeping the transhumance practices alive and most of them express their appreciation to living in close proximity to the animals (Bonow and Rytkönen, 2013).

What is striking is that the farm dairy sector in Jämtland is neither a modern industry nor a traditional artisan trade - it is a mix of both. This very condition is part of the answer to how this trade managed to emerge and it also illustrates which are the principles that the future survival of the sector relies on.

One important feature of the farm dairy sector is that an obvious positive spatial effect can be observed over time, which is an important explanation for the expansion of farm dairies and of the success of the trade at national level. In previous research, positive economic results caused by various types of agglomeration have been well studied (see, for example, Krugman, 1991; Head et al., 2002; Carlsson et al., 2000; Porter, 2000; Ciccone, 2002; Åquist, 2002; and many others). Within the rural context, the globalization of the agro-food system has led to a new governance model, in which new consumption models, globalized retail, technical progress and constant price pressure on farmers emerged, which forced farmers to de- velop new (business) strategies. An important issue in current development is that agglomeration has become a central element for economic development in rural areas (Sforzi and Mancini, 2012).

While the emergence of local food systems with a high territorial anchorage are more common in other European countries, the farm dairy sector in Jämtland breaks the previous Swedish pattern of self-sustained rationalization and centralization. As such it is a pioneering experience worth studying. This article will highlight the articulation of the farm dairy sector, characterizing its links the territory by highlighting the historical, cultural and landscape characteristics that remain and how these blend with modern practices. As the article will rest on LAFS approach, the main question to be answered is: Which are the milestones in the articulation of the farm dairy sector and the LAFS that grew within the frame of the sector? Which are the main characteristics of farm dairying in Jämtland today? And how do these elements contribute to the creation of value within the sector?

In addition, as the re-construction of the sector has partly been influenced by foreign knowledge. Which are the consequences of this foreign influence on the creation of value? And, does it compromise the genuine Jämtlandic character of the trade in the eyes of the consumer?

The article is organized in five sections., an introduction with a presentation of the method and sources, a theoretical discussion that introduces to the concepts that will be used to organize the study, a historical introduction to dairying in Jämtland, an empirical presentation, which is organized according to the selected theoretical concepts and where events are presented chronologically, and finally the article ends with a discussion and conclusions.

\section{METHODS AND SOURCES}

The results for this article are based on a case study on farm dairies in the county of Jämtland. The case study grasped in-depth interviews, triangulation of information using written and oral sources and statistics, landscape analysis, observations and a document study of contemporary and historical data on the dairy sector in the county. The total population is composed by 28 farm dairies and a total of 24 farm dairy owners were interviewed along with key agents in the area, such as representatives for the County board administration (CBA) and the National Center for Artisan Food, Eldrimner (it is located in the area), and a veterinary. In addition, a focus group held with representatives from Jämtland Härjedalen Tourism, the regional section of the National Farmers' Association (LRF), a regional food organization (Matstråket), two representatives of the Regional Council Jämtland, the director of Eldrimner and an artisan beverage producer targeting issues related to territorial development. And finally, the case study also grasps a consumer survey was conducted outside five farm dairies in the area. The locations were farm dairies with farm store and café. In total 161 people answered (91 women and 70 men). Although just parts of the information shared in the interviews is of 
a sensitive character, all results from producer interviews have been anonymized, while representatives of public authorities have been quoted with name. It is important to state that only the interview results relevant to this article have been used. ${ }^{2}$

\section{RURAL DEVELOPMENT BASED ON TERRITORIAL RESOURCES}

The productivist, top-down agro-food governance model implemented in Sweden during a major part of the $20^{\text {th }}$ Century was a necessity to lift the Swedish population out of poverty, by re-allocating labour force from agriculture and rural areas into urban industrial ones. The model created a self-sustained and path dependent process of constant productivity chase decimating the number of farms and food processing plants. This is especially true for the dairy sector.

By the late $20^{\text {th }}$ Century and especially after Sweden entered the European Union in 1995, the desired transfer of resources from rural to urban areas had instead become a problem. Rural areas were becoming quite depopulated as Swedish farms lost their competitive power, especially in relation to some of their European counter parts (Jordbruksverket, 2003 and 2013). The decoupling of agricultural subsidies in 2003 offered a possibility to rephrase policies and a totally new course was set out with the purpose of creating a shift of policies from a focus on agricultural production to a broader rural development goal (Regeringsskrivelse, 2003/04: 137 and SOU, 2006: 101). The shift is described as highlighting "place based firms" (farms and other rural firms) as a new and strategic resource for future growth (SOU, 2006: 101).

Although the latter is a general description for rural development in Sweden, in an inland county like Jämtland, such acute problems were a reality already in the 1970 's. In spite of subsidies, the migration from Jämtland to other parts of the country, changing patterns of consumption and the physical characteristics of the landscape, forced regional authorities to take measures to prevent a further drop in the number of small scale farms already during the 1970's.

The actions taken in Jämtland to cope with the above mentioned challenges, led to a pioneering experiment of handicraft industry development that served as an inspiration for recent policies. Such experiences are not new in other European countries. They are all part of what some times is called the new rurality, a concept used to broadly describe the new rural development strategies that try to cope with the challenges of globalization.

In the academic debate, the new development is expressed through studies on the process of re-localization of food circles around the emergence of alternative, short food chains, networks, rural clusters and local production systems. Local circuits are tightly connected to globalization, because they are a response to globalization (Arfini et al., 2012: 2). The re-localization of food led to the emergence of new relations between farmers, consumers and other agents and are defined departing from the nature of their interaction. Re-localization entails that a new role is played by food quality - as the properties of food are valued beyond nutritional values and safety, but are also recognized as carriers of cultural heritage, local values and trust between consumers and producers. Often the re-localized food circles use quality schemes implemented by so called alternative agro-food networks, AAFN (Higgins et al., 2008: 15-27). One condition of re-localization of food is that it entails a new type of governance, grasping vertical and horizontal multi-level organizations of agents, resources and the territory under a new frame of governance. In all cases territorial governance, defined as "the process of territorial organization of the multiplicity of relations that characterize interactions among actors and different, but non-conflictual interests and construction of a shared territorial vision" (Davoudi et al., 2008: 37).

There is a wide variety of AAFNs, with different features depending on the resources that are mobilized and how these are organized. In local production systems stakeholders are in general located in the same place with short distances between them (Courlet, 2008). As Jämtland is a county with sparsely populated areas and low population density, the distance between producers and consumers is substantial. However, in spite of the distances, the farm dairy trade shares territorial features that contributed by linking stakeholders together in a development process. Territorial features comprise historic-cultural links, material and immaterial links, landscape, people (Muchnick, 2009: 9-13) and in this case also animals and products. According to Boucher and Pomeon (2010), when territorial resources become activated in a process of structural collective action (e.g. by creating an organization within which local stakeholders can cooperate) and functional collective action (which entails the qualification of a territorial asset through a collective mark, brand or geographical indication) in which the territory becomes and agent for the constitution of a LAFS (Boucher and Pomeon, 2010: 8 ). Such process enables the mobilization of collective strategies and the productive system becomes localized rather than local. It becomes possible to build a LAFS that embraces an entire region, even though its components are "a set of micro-basins in a region, a kind of archipelago" (Requier-Desjardins, 2007: 11).

The concept of Local Agro-food Systems (LAFS) relates to a process in which resources, know-how and products become adapted to and rooted into a territory and that can be used to promote and sustain innovations through productive, social and cultural activities (Muchnick, 2009). There are countless studies of the process, therefore a number of best practice models have been elaborated on how to design a LAFS. Muchnick (2009) argues that the study of a LAFS process comprises studying (a) the coordination of stakeholders, social networks, collective actions; (b) the qualification of products - often involving a geographical indication - and development of institutional frameworks, rules and regulations; (c) the dynamics of knowledge and competences grasping the interdisciplinarity involved in such a process; (d) resource management, involving natural resources, cultural 
heritage and appropriation methods. There is a general consensus in research on the correlation between creation of value and the presence of an organization within which collective action takes place around the qualification of a product in relation to its territorial characteristics. Most often, this qualification is composed by a geographical indication, GI (See for example Barjolle and Sylvander, 2000; Hayes et al., 2004; Ribeiro and Santos, 2004; Joslin, 2006; Bérard and Marchnay, 2007; Reviron et al., 2009; Vandecandelaere et al., 2009; Barraclough, 2011; Belletti and Marescotti, 2011; and many more).

The Jämtlandic case differs from what main stream LAFS studies previously denominated as essential features of a LAFS, for example no geographical indication has been used and know-how has been obtained from other countries to fill the knowledge gaps that nearly 100 years of intensive industrialization and dismantling the handicraft food production left behind. In addition, previous studies emphasize the crucial importance of local resources and know-how, but the process of qualification of local resources in Jämtland also involves foreign knowledge and know-how. In spite of existing differences, there are also important similarities, concerning the mobilization of collective action, the appropriation of local knowledge in an innovation process that led to the development of localized products that are characterized by territorial resources and linked to local culture and history.

Although all concepts used in the previous discussion could in different ways contribute to highlight different parts of the LAFS process in Jämtland, in this article the main emphasis will be put on structural collective action and functional collective action. These will contribute to highlight the LAFS process as well as identify the territorial features, e.g. the historic-cultural links, material and immaterial links, landscape, people, animals and products.

\section{HISTORICAL BACKGROUND}

The county of Jämtland is located in the Northern inland parts of Sweden and is the least populated county, with a total of 12 percent of the national area and only 1.4 percent of the national population. The population is scattered along the entire county and distances between settlements are quite large. The physical characteristics are dominated by mountains and the agricultural season is short. Farms have historically been quite small. Today only 1.3 percent of the total area is used for agriculture and existing farm dairies are scattered all over the territory.

The general characteristics of Jämtland make business establishments difficult, therefore agriculture and forestry have remained the main trades since traditional times. During the $19^{\text {th }}$ Century the implementation of state of the art technologies and practices laid the foundation for increasing agricultural productivity and escaping from recurrent periods of food scarcity. The first reliable estimations of agricultural conditions were made in 1817 . These state that husbandry was the most important economic activity, while only 10000 hectares of land were used for various cultivations. By then, hayfields were the only source of fodder, which only allowed an extensive dairy production and husbandry system and made summer grazing in forests and remote areas a necessity (Åsling, 1967: 14).

The process of modernization in husbandry and dairy production led to the inevitable separation between the traditional transhumance and mountain based farming/ husbandry system and modern agriculture. Farms that had sufficient means and geographical conditions to embark in modern husbandry benefited from the agricultural education centers instated during the $19^{\text {th }}$ Century, the start-up of a breeding station and knowledge about new practices for forage cultivation and conservation. Modernization led to a fast rise in the number of specialized dairy farms and eventually also of industrial dairies (Svedjeland, 1964). The increase was especially fast between the 1860's and the 1930's driven by butter export possibilities to the UK (Staffansson, 1995). This expansion ceased abruptly when excess supply of butter on the world market led to the forced organization and rationalization of the entire dairy industry. For the industry, this meant that a process of selfimposed rationalization was initiated (Svedjeland, 1964; McPherson, 1997; Åsling, 1967).

The number of industrial dairy plants became decimated over time through a number of mergers between cooperatives in the area. In 2000, there was only one remaining industrial dairy cooperative that stretched over several counties, including Jämtland. This cooperative, Milko, ceased to exist as it was forces to merge with Arla Foods in 2012. As the number of industrial plants has decreased, the pressure of increasing production and raising productivity on the number of dairy farms has increased. This has stimulated the support towards the farm dairy sector as it has gradually taken the place of the conventional dairy industry concerning the creation of employment opportunities and the generation of income in the county.

Parallel to the modernization of the industry, traditional goat farms or mixed cow and goat farms continued to exist throughout the $20^{\text {th }}$ Century. The number of farms decreased when people moved away in search of new job opportunities but they never disappeared completely. Traditional agriculture survived in Jämtland for several reasons. First of all, the tradition of being members of the local/regional cooperative was strongly embedded in dairy farmers, not only in Jämtland but all over the country. Goat farmers were also members of the emerging industry, thus the dairies had to receive their milk, even if deliveries were seasonal and quantities were small. In fact, at the country archive in Östersund, ${ }^{3}$ there are plenty of price lists preserved from the 1940's, 1950's and 1960's that show that French style goat cheese was made at the industrial plants in the region. In addition, unlike the rest of Sweden, as the local population was accustomed to consume goat cheese, the industry had an incentive to also use goat milk and to collect milk from quite small farms. The assortment based on milk from goat farms was terminated in 1984, as transaction costs for collecting the milk had become too high at the same time that demand was falling. As long as the industry received goat milk, it was possible for people to keep their farms. Moreover, some tra- 
ditional farms never stopped the practice of curdling, of producing traditional products and dishes and selling these at local markets and/or selling directly to consumers (Interview Göran Henriksson, 20104).

Traditional/extensive husbandry in Jämtland has deep historical roots in the Jämtlandic (or Scandinavian) transhumance system. In Sweden transhumance is called Fäboddrift. Transhumance is composed by the combined use of fodder production in the hayfields close to the main farm and the use of summer pastures in the often remote summer farms (fäbodvall) where the animals, Swedish alpine cows and Nordic goats (also called jämtgetter), graze in the hayfields and forests that surround the summer farms. The grazing system is called in-field, out-field. At the summer farms, an important task for the dairy maids (fäbodjäntor) was to guard the animals and milk them to make various types of products and dishes for the coming winter. Some charcuteries, such as sausages, were also made using the animals' meat. At the summer farm the cheeses were stored in store rooms or earth cellars while waiting for the transportation down to the main farm, where the final storage was done in earth cellars. The summer farm itself is often composed by a small residential building, a barn for the animals (fjös), a cellar for storing dairy products, a dairy (kokhus) and a bakery (bakstuga). The summer farm might belong to a village, but it most often belongs to a single farm that is located closer to a village. The right to use the meadows and forest for grazing (mulbetesrätt) is written in the title deed of the farms. The use of summer farms is not unique for Jämtland. In historical times the use of summer farms was practiced from the North of Uppland (Central Sweden) and up to Northern Norrland (Larsson, 2003).
Summer farms have in a clear way characterized the food culture in the County of Jämtland since historical times. Goat cheese and milk dishes were served both in daily life and more festive occasions (Berglund, 2006: 7). According to ethnologist Nils-Arvid Bringéus (1997), transhumance was the most important and distinctive feature of food culture in the Northern parts of Sweden in previous times. Goats were used primarily to produce cheese and whey cheese (mese), while cows were used to produce cheese, whey cheese, butter and thick milk (tätmjölk), ${ }^{5}$ but also many milk dishes, such as grain cheese (grynost), sweet cheese (sötost) and floated porridge (flötgröt). Since butter already in historical times was an important trade item, it was produced only with skimmed cow milk. Skimming goat milk is quite difficult; therefore it was mainly used for cheese and whey cheese. An additional reason for producing cheese was that butter gets rancid after a couple of months, while the cheese could be stored for a whole year (Berglund, 2006: 7).

Today, the stock of active summer farms has become decimated. The vast majority of summer farms are today used as holiday cottages. Not all active summer farms have commercial dairy production and the ones that have commercialized their business have kept traditional practices in varying degrees.

In the interviews several informants claimed that there are summer farms on which non-traditional meat cattle are kept, which made many of them quite upset The summer farms included in the sample have kept their dairy production, some changed parts of the production practices, while a few, like Myhrbodarna (see picture below) have maintained all of them. Owners of summer farms also have fishing and hunting rights, which today is used both for private use and for tourism.

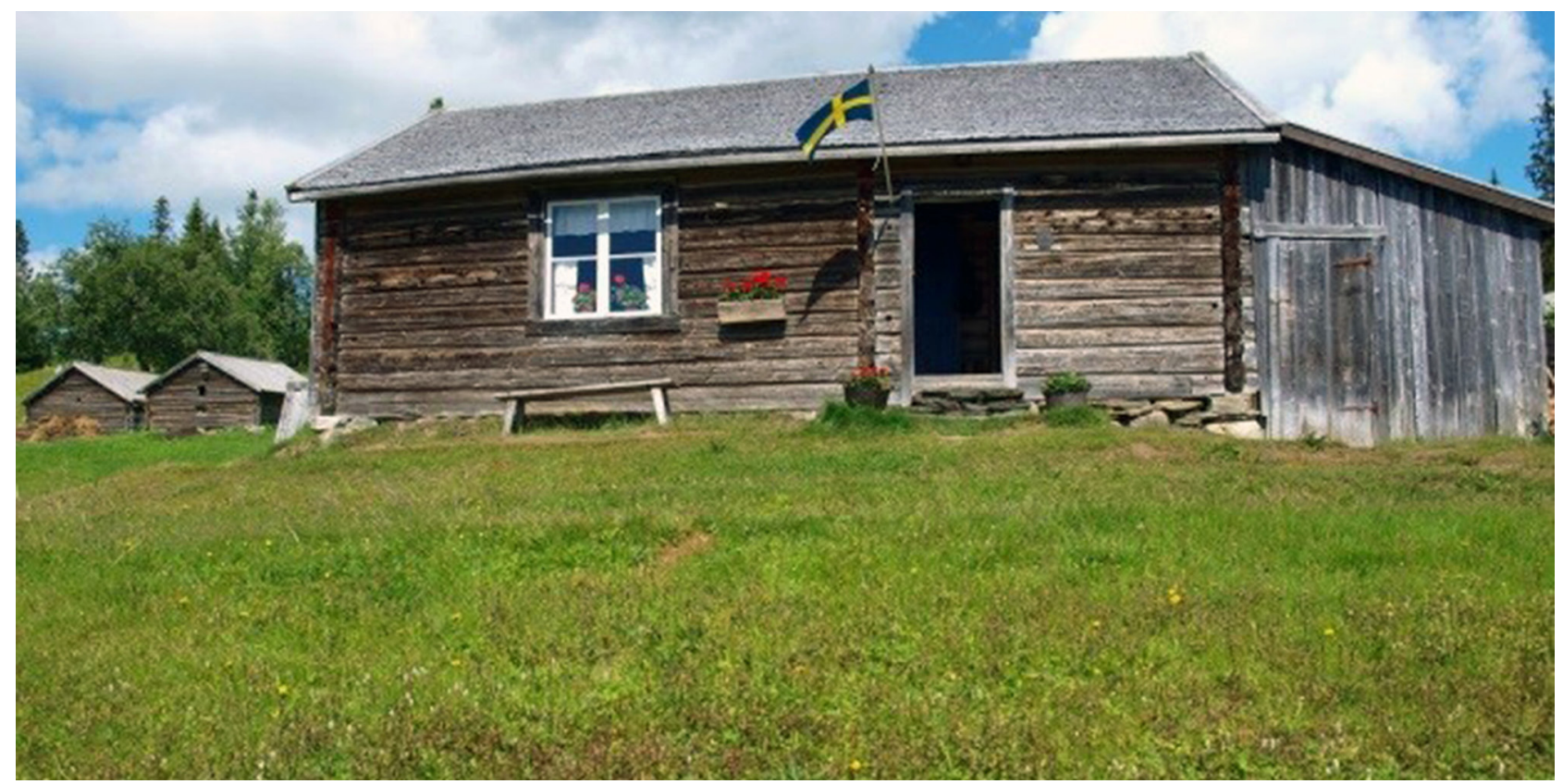

Рното 1. A typical summer farm. At the front is the residential house with the toolshed on the right. On the back left are the barn and milking house. 


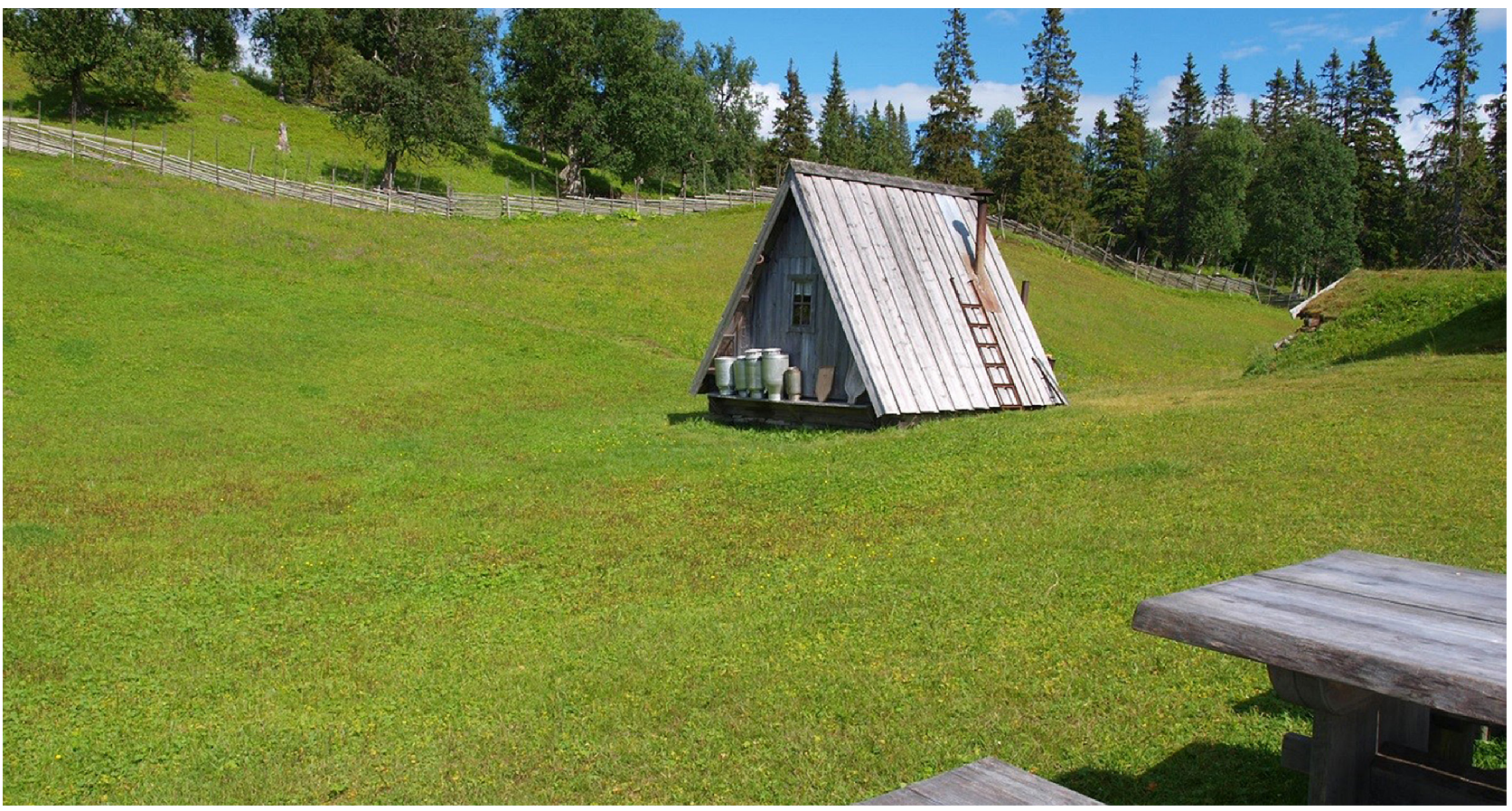

Рното 2. A dairy, located behind the residential building.

\section{THE LOCAL AGRO-FOOD SYSTEM PROCESS AND VALUE CREATION}

\section{Establishing structural collective action}

The farm dairy sector in Jämtland started to emerge when in the late 1970's the industry announced that they would stop processing goat milk in 1984. By then, the County Board Administration initiated a program to support goat farms. This was a controversial project at the beginning, as many people employed in the CBA did not conceive the importance of developing the goat sector; instead they tried to hang on to the productivist paradigm. The responsible public official claims that: "as long as I kept out of the way of projects with 'real animals' (e. g. cows or pigs) I was allowed to conduct my projects" (Cormell interview, 2010).

At the time there where around 50 goat farms left in the county. A project called "Swedish Goat Cheese" investigated the possibility of investing in joint marketing and product development for the Jämtlandic cheese. An important conclusion of the project was that there was an over production of traditional cheese and the market was rapidly shrinking. This project laid the foundation for the following events. This process was supported and initiated by regional authorities:

- The support for the foundation of a commercialization cooperative to launch and sell goat cheese in 1983.

- The CBA fully equipped two mobile dairies in 1987. These dairies are rented for a period of two years at a very low cost, which offers the farmer a smoother introduction to the business and the possibility of building up a business before making the commitment in building a dairy. These dairies are still in use.

- The establishment of a training center to support artisan food. At first this was a series of courses on curdling, business knowledge, marketing, etc. financed by the CBA; in 1995 a formal organization, Matora, was established; and in 2006 this organization received government support and became a national center for artisan food. An important method used since the beginning has been to organize inspirational trips to other countries, where the farmers can get knowledge and find inspiration from what people do elsewhere.

- The start of national food artisan contests (SM I Mathantverk), where contestants can challenge each other and can win a gold, silver or bronze medal. Winners get stickers to stick on the winning products during the following year.

All actions mentioned above facilitated the expansion of the food artisan sector. Actions and events also paved the way for the articulation of a new institutional frame that made the emergence of a small scale food industry possible. The new regional infrastructure provided by Matora (from 1995) and later on Eldrimner (from 2006) was quite important to help breaking the institutional barriers caused by the path-dependent, main stream agrofood development (Rytkönen et al., 2013).

At the micro, firm level, the president of the goat breeding association, initiated together with six other goat farmers a cheese cooperative in 1983, Jämtspira. The initiative received the financial support of authorities. ${ }^{6}$ Their business model entailed having a common warehouse and joint 
distribution, while production was to be made on the farms. They were inspired by examples from France, where small scale dairy cooperatives are common. (Rytkönen et al., 2013; Rytkönen et al., 2014; Stryjan et al., 1991).

In Swedish cooperatives it is tradition that raw materials, such as milk, are sent to the cooperative industrial plant for elaboration, thus Jämtspira was breaking new ground when they decided that elaboration of cheese was to be made on the farm. The consequence for farmers was that curdling traditions and know-how could be kept and also developed on the farm. An additional feature was that decisions were kept locally, or as one of the informants expressed: "We were only six families at the beginning and we made decisions around the kitchen table."

Jämtspira was an important milestone in the articulation of the farm dairy sector because it provided a platform for newly started farm dairies for marketing their products, exchanging knowledge and to break the isolation that otherwise can affect rural firm owners. Several of the informants highlighted the importance of the creation of a peer spirit, just having somebody to call when something was going wrong in the dairy or when advice was needed and the nearest colleague lives 100 kilometers away was mentioned time and again during the interviews as the most positive feature of Jämtspira. When Jämtspira grew, the organization gradually crumbled apart as some of the dairies became much larger than others and it was finally terminated in 2010 , but by then public authorities had taken over the role creating a meeting point, not only for farm dairy owners, but to all food artisans through the creation of Eldrimner in 2006.

Over the course of 17 years a total of 20 goat farmers had been members of Jämtspira and when it closed down in 2010 the smallest of them produced an annual output of 4-5 tons of cheese, while the largest member produces 120 tons annually and employs 10 people in the dairy alone. Herd size varies greatly but the smaller farms have herds of 30-60 goats, while the largest farm has between 400 and 500 goats, without counting kids (Bonow and Rytkönen, 2013).

It is important to end this section by highlighting economic outcomes, as they shed light on some of the difficulties met, or generated during this process. Most producers have benefited from the creation of Jämtspira and the collegiate spirit created by their precursors. But not all managed to make a good living. Producers have two sources of income. One is generated by sales of products, services and tourism activities, and the other is generated by subsidies from the rural development program. Most informants claimed that they don't apply for subsidies although a have a right to do so. But, reality shows that especially the smallest production units are dependent on them. One of the informants claimed that the year before the interview, the public officer that handles the subsidy applications at the CBA managed to make a mistake that led that she did not get the subsidy that year. For her this meant that, as she has not managed to get a profit from the dairy yet, she did not have any salary that year.

A similar story was presented by another farmer. She is one of the oldest ones in the sample and she claimed that she stopped applying for funding because she felt that she was poorly treated by authorities. She expressed her frustration by sending the following poem to the CBA:

Bästa herr eller fru kontrollant,

jag är en medelålders gammal tant,

rätta mina fel och brister

så jag inte bidraget mister

Dear $\mathrm{mr}$ and $\mathrm{mrs}$ inspector

I am a middle age, old aunt

correct my mistakes

so I do not lose the grant

The farmers that managed to generate an income that allows them to live of their business have been forced to invest and increase the size of their operations. Some of the informants had the means to invest and could therefore generate a full salary more rapidly. But for the farmers that were forced to borrow to build their dairy plant financial conditions are more difficult.

Finally, did collective action save the 50 goat farms that were active in the early 1980's? The answer is just a few. Five of the goat farms had merged into the largest farm dairy in the county (Skärvångens village dairy), six had secured survival as new generations had recently taken over and three had just started their businesses. All other farms were gradually closed down as old age or illness forced the owners to close down and there was nobody to take over. Most current dairies are relatively new. A new generation of both locals and city dwellers started new farms and new farm dairies with varying success.

What kind of institutional frame was created around the farm dairies? Since Matora was founded in 1995, authorities have had a proactive attitude, contacting and supporting newcomers and new potential food artisans. In addition, in 1980 all public structures were organized to support and control large scale, or at least industrial operations. The farm dairy sector was forced to break new ground when they pushed for a more flexible legislation and implementation of current legislation. They were the first artisan food trade that gained recognition when the National Board of Food accepted the elaboration of industry guidelines for farm dairies in 2009. The industry guidelines for farm dairies were the first to be adopted in Sweden. Now there are industry guidelines for several food artisan trades, including summer farms. The latter finally got recognition in 2014 with an own industry guideline (Eldrimner, 2014).

\section{Establishing functional collective action and product innovation}

To address the problem of over production of goat cheese in 1983, a process to develop new products was initiated. One of the founding members of Jämtspira explains this in the following way:

Only the older generations bought the traditional red chesses, that by then looked like small rabbits (dark in colour and hairy from the cheese molds). Modern con- 
sumers were suspicious and had been educated with modern practices. The cheeses they bought were bright in color and packaged in airtight plastic. Our response was to develop a modern product that could appeal to younger people. ${ }^{8}$

The first new cheese was Vit Caprin, which was a more modern version of the traditional white goat cheese. This cheese was developed based on local knowledge and local experience. The initial members of Jämtspira took turns in promoting the new cheese. One of the informants claimed that:

Each family took turns to demonstrate the cheese in fairs and other public places we virtually sliced cheese into people's mouth for a period of two years. And that is how we managed to find the consumers that were willing to buy our products. ${ }^{9}$

But a short while after Jämtspira was founded, foreign influences became visible. The first two cheeses that followed were a blue cheese called Getbleu (a blue cheese) and Estragon, both developed from French models (Styrjan et al., 1991). These cheeses not only had foreign names, but their production also followed foreign recipes, thus the only local component was the milk. In fact, during the late 1980's cooperation with the French curdling specialist, Michel Lepage, was initiated. He has since spread a large number of foreign, mainly French cheese recipes and also taught the art of producing them. The production of foreign cheeses has also been promoted through the many inspirational trips that the CBA and later on Eldrimner organize every year. Cheeses like "Rocka fett" (rock hard from Roquefort recipe), Granbarksost (pine bark cheese from a foreign recipe), Kozzarella (cowzzarella from mozzarella recipe with cow's milk) are some examples of the many cheeses now produced by the trade.

Although the initial reconstruction or modernization of the trade was facilitated by copying foreign products, which helped the market for new goat cheese and artisan cheese market become more mature. In addition, a demand for genuine and traditional products begun to sprout.

In 2006 a cream cheese that no longer was in production - Vålåloffen - was recreated. The Vålåloffen cheese was invented by a Norwegian curdler that was active in the valley of Vålådalen during the middle of the $20^{\text {th }} \mathrm{Cen}$ tury. The name of the cheese translates Vålå (from the valley) and loaf (loffen is Norwegian for loaf of bread). Many of the producers had eaten the cheese in their childhood and they had fond memories of it. In 2006, the regional dairy, Milko, transferred the right to use the trademark of Vålåloffen to an association of farm dairies, Jämtländska ostsyndikatet (Jämtlandic Cheese Syndicate). The association was composed by some of the members of Jämtspira and a qualification process was initiated to apply for Protected Designation of Origin for the cheese. When the application was completed the leading partner in the association decided not to submit it. The other producers claimed during the interviews that they did not understand this decision. ${ }^{10}$ And the leading partner justifies it in the following way: "we were already charging $450 \mathrm{scr}^{11}$ for a kilo of cheese. Applying for a PDO means that we need to raise the price even more and as I see it there is no room for higher prices". ${ }^{2}$

Although we did not get a straight answer to why they had embarked in such a costly process to just through all efforts away, a reasonable explanation is that the process was expected to generate a lot of publicity and of additional support to re-launch the Vålåloffen cheese, as well as to obtain the right to use the trademark. Moreover, the knowledge on what geographical indications are and how they work is still scarce in Sweden (Rytkönen and Gratzer, 2012), it is thereby reasonable to assume that the producers could not see the value that they could obtain by actually getting a PDO.

In 2004, an Interreg project called "Search for Old, Create the New" (Söka gammalt skapa nytt) with stakeholders in Tröndelag, Norway and stakeholders from Jämtland, initiated an inventory of traditional local artisan food knowledge and local food culture in Tröndelag and Jämtland. The project led to the restoration of old cheese cellars and the rebirth of cellar stored goat cheese (Källarlagrad getost) (Berglund, 2006). Nine farm dairies participated, sharing the traditional knowledge about cellar stored cheese. In 2005 the producers initiated a process to certify this cheese with Slow Food Presidia, which was successfully achieved a short while after. ${ }^{13}$

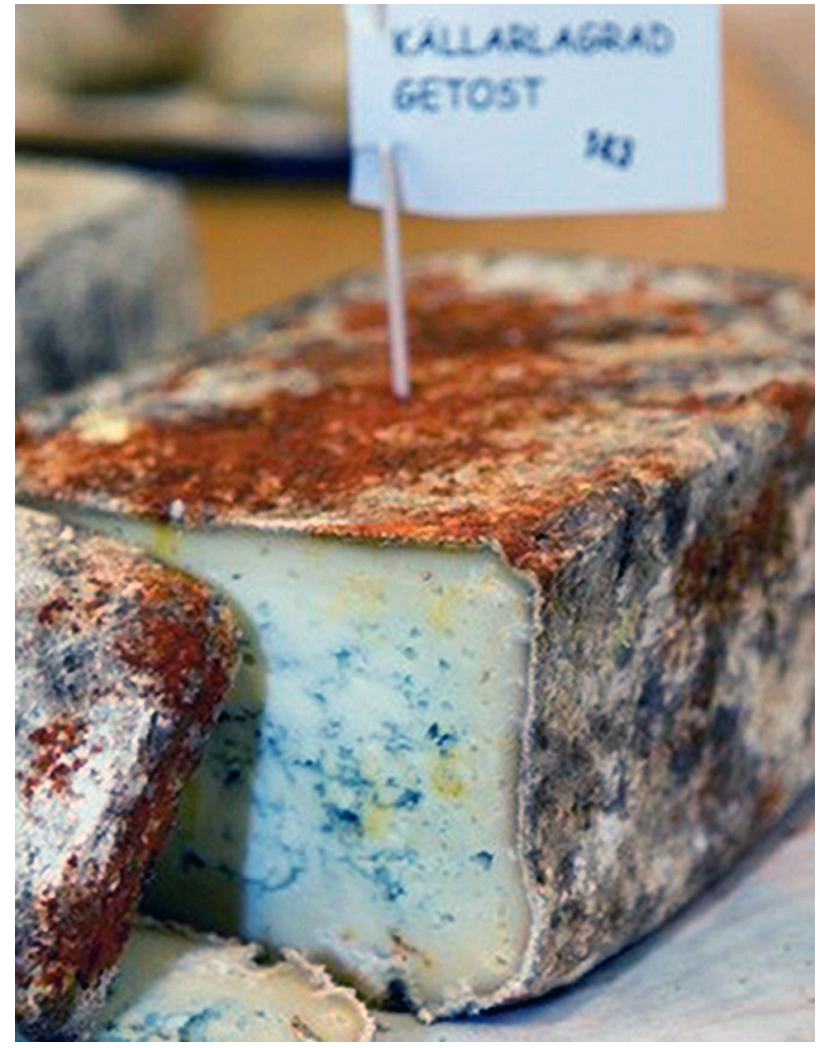

Рното 3. Cellar stored goat cheese. Photo by Anna Berglund Eldrimner 
In spite of the foreign influences, during the last 10-15 years, traditional cheeses have become popular again. One example is the "moving cheese" (flyttost). This cheese was traditionally made with a blend of all the milk that was left in the summer farm when it was time to leave to the main farm. It is now made in larger quantities as its intense taste with mild smell has made it a popular choice amongst consumers of all ages. There are also a number of nameless cheeses that go under various names, for example "Christmas cheese" (made in a summer farm and sold in advance and delivered for Christmas). Another that is made by one of the younger dairy maids' calls her most traditional cheese for "stinky." It is a stored cheese with a light colour and quite strong taste and fragrance.

Departing from the above mentioned examples it becomes possible to question if the foreign influence on farm dairies is harmful. The foreign influence and recipes have meant that young consumers who were previously suspicious of the artisanal products have dared to try the traditional products after trying the more modern "foreign model" cheeses. The "foreign" cheeses helped creating a new demand for the traditional products. Informants confirm this as they argue that the foreign knowledge filled an important knowledge gap and that the "foreign" cheese opened up the interest for artisan cheese production and generated the necessary income for their firms to survive and prosper. When the interest for locally produced artisan cheese once was established, the demand for traditional cheese was "a natural step for consumers."

There has also been a process of appropriation, as producers put their own touch on products, making slight changes in recipe that create noteworthy variations in the sensory qualities of products, through taste, smell and texture. Also the names of the products are local and many times with a touch of local humor.

The dairy traditions of Jämtland also included several other products and dishes. Most farm dairies run cafés or farm stores at the farm. In most cafés it is possible to consume a cheese buffet, drink coffee, or other alcoholic and non-alcoholic beverages. Some offer modern varieties of coffee with a traditional touch, for example a cappuccino with a spoon of whey cheese, others serve ice cream based on whey cheese or goat milk. Of the traditional dairy dishes in Jämtland the only one served is waffles, which only became a tradition in recent times. Charcuteries can hardly be found, but recently one of the dairies started to make sausages and hamburgers, that visitors can grill over an open fire. Other dishes like vassledricka (whey drink), grain cheese (grynost), sweet cheese (sötost), or floated porridge (flötgröt) are no longer produced nor served.

In a few of the summer farms, shores that used to be part of the work to secure enough food for the winter have become commercialized through tourism activities. Amongst these are hunting and fishings. Tourism offerings include meals that are composed by modern dishes but that are prepared with local ingredients. The only dairy products served to tourists are cheese, whey cheese and thick milk. Thus commercializing the traditional dairy trade in Jämtland and opening up for tourism has meant that a few compromises have been made. While some new practices have been adopted, others have been lost. Some traditional products have found a new place in the modernized trade, while other dishes and products did not. According to Muchnick (2009), this is quite natural, as products that once were localized might disappear, while new ones become adapted and adopted by the people and introduced to traditions and local culture. The functional collective action process described above, not only led to the identification and qualification of territorial assets, when old products were re-created and relaunched. It also generated a process in which qualification has been re-produced creating the virtuous circle necessary to sustain a territorial development process (Vandecandelaere et al., 2009).

\section{Landscape elements and reproduction of values}

An important factor influencing the sensory quality of milk is pastures. There is a variation concerning what the animals eat at the homestead. The sensory qualities of milk properties at the farm dairies with mountain flats and on summer farms is highly influenced by what the animals find in the outfields. The hike from the homestead to the summer farm takes place around the third week of June and the return to the homestead takes place in $\mathrm{Au}-$ gust or early September, depending on the weather. At the beginning of the summer there are herbs and flowers and in the autumn the animals eat various types of mushroom. Thus, the products, especially the cheese get a milder taste at the beginning of the summer while they get a stronger and nutty taste at the end of the summer. One informant expressed this in the following way:

You see the animals grazing like militaries on a row - when they come home you can smell what they have eaten. In the autumn you can almost see that the milk has a touch of yellow from al the mushrooms. ${ }^{14}$

This variation in taste and character distinction of the products is of course not possible for the farm dairies that use conventionally produced cow milk, but the permanent goat farms, the summer farms and the mountain flats all enjoy the marks that seasonal variation in vegetation make on the products.

Grazing produces additional values that are highly demanded by authorities, but also by tourists. One such value is the promotion of biodiversity. Biological diversity is driven by competition between species, which means that competition leads to species-poor habitats with a few strong species. The hay meadows in Jämtland reproduce a habitat that is beneficial for weak species. In Annex 1 in the Habitat directive the habitat type 6520 Mountain hay meadows are described as; "Species-rich mesophile hay meadows of the montane and sub-alpine levels." Some of the species that exist just thanks to grazing and mowing are Mountain Everlasting (Antenar- 
ia dioica), Marsh Grass of Parnassus (Parnassia palustris), Bluebell bellflower (Campanulla rotundifolia), several species of Eyebright (Euphrasia), Black Gymnadenia (Gymnadenia nigra), White Mountain Orchid (Pseudorchis albida) and Field Gentian (Gentianella campestris) (Rytkönen et al., 2014; Tunón et al., 2013). One important practice in the summer farms is the spring burning (vårbränningen), a slash and burn practice that has guaranteed that the forest does not take over hayfields. ${ }^{15}$ The extent to which all farms depending on the in-field, outfield system still practice spring burning is not known, but without this practice it would be difficult to have enough grazing today.

There is also a rich variety of wild animals. Some of them are predators, for example bears, wolves, lynx, wolverine and golden eagle (Länsstyrelsen, 2014). During the $19^{\text {th }}$ Century, the Governors used to account for the number of predators that were killed and hunting predators was encouraged. Today the hunting of predators is strictly regulated because of the risk of extinction, especially of wolves and bears. All informants with summer farms see this as a problem since their animals sometimes get eaten. But in spite of the problems caused by predators, their very presence leads to the reproduction of another key value, namely maintaining the traditional knowledge carried by the landraces that are used in traditional livestock farming.

Many Informants claim that the older animals teach the younger ones what to eat and where and how to avoid predators. Informants' observations are confirmed by research that claims that the ability to avoid predation is a property that traditional breeds developed and maintained to a greater extent than other breeds. Studies in sheep in Norway have shown that traditional breeds have a behavior with higher vigilance and better escape and flock characteristics than what other breeds have (Hansen et al., 2001).

Finally, farm dairies have meant that two land races, the Nordic goat and the Alpine cow have acquired a financial value. Creating a financial value for landraces has been proven to be an efficient method to avoid extinction, for example in the autonomous Spanish region, Cantabria, several landraces were saved from extinction as their milk was inscribed in the product specification of two protected designations of origin, Picón Bejes Tresviso and Quesucos de Liébana (Rytkönen and Gratzer, 2012: 38). The same luck is not shared by the local breeds of sheep, which in the past also used to be part of the herds in Jämtland. But they disappeared before our time, exactly when is unknown. ${ }^{16}$

\section{Produced values and consumers}

In the previous sections, the reproduction of cultural and natural values has been discussed along with parts of the innovation process. But although substantial values are created, it is essential that these values are transmitted to the consumers that are supposed to purchase the products and services. In fact, all firms use territorial values as parts of their trademark or image in order to achieve consumer loyalty and establish a relation with the market. This is in turn achieved by awakening consumers' feelings, which is an important part of the purchasing process. And most important, this is also something that firms can influence through the design of their products, the package, marketing and story-telling (Van Ittersum et al., 2003). In the rural context origin and the social and geographical history of products is often used to create competitive advantage (Bonow and Rytkönen, 2013; Morgan et al., 2006: 3; Ilbery and Kneafsey, 1999: 2208). Territorial anchorage can thus strengthen the trademark of a firm or a product.

In Jämtland, this is a dominating strategy. Goats, alpine cows and the mountains adorn most of the firm and product logos, showing the specific anchorage to the territory. The products have been given traditional names and some have depicted dairy maids on the products by giving the names of some of the dairy maids that worked at the farms. Also nature values as biodiversity, and maintaining the traditional mountain life-style are transmitted (Bonow and Rytkönen, 2013). Territorial attributes are used by all the farm dairies except for two, in which the owners have decided to sell their products in unbranded packages, refraining from advertising. In both cases, owners passed their retirement age and they lack successors to the business. All other informants say that the names, logos, ways of selling and story-telling help the consumers to remember the products. In theory this is denominated as giving consumers a "sense of place" (Ilbery and Kneafsey, 1999; Van Ittersum et al., 2003; Von Friedrichs and Skoglund, 2011).

In the consumer survey conducted in 2012 , the statements and actions were put to a test as consumers were asked to offer their perspective on what they are willing to pay for. The survey covered questions related to the importance of trademarks, brands, logos and quality distinctions, the role of the territory, and the role of demo-

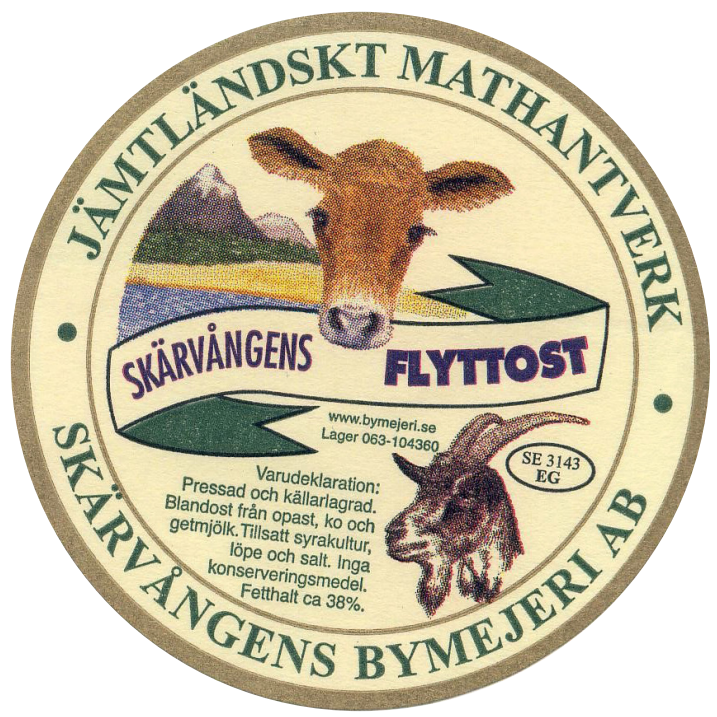

Рното 4. Example of a typical product logo. 
graphics and income on the purchase decisions. The results show that income and age, as well as trademarks had not influence over the buying decision. Consumers were of all ages and had all types of occupations and income. But the consumers' origins did play a role for buying the products. Many of the consumers had their origins in Jämtland as either their grandparents or parents were born in the area. Many of them live in other parts of the country, but there were also a substantial number of local tourists.

Why do people buy the products? The majority, $70 \%$ answered that it is because the products taste great, but people also appreciate the staff and owners at the farm dairies and the landscape. Surprisingly, comments about the contribution that farm dairies make to the creation of employment, of attracting tourists and bringing life to small communities were also rated as quite important. Younger consumers appreciated the possibility of getting a culinary experience to satisfy their growing interest for "food with history" and "high culinary value." These consumers also expected a high level of service and standard to be kept; therefore not all farm dairies were appreciated. Other, older consumers were more nostalgic and referred to childhood summers and their grandmothers' cheese and butter. A few consumers mentioned nature and the animals.

\section{CONCLUDING REMARKS}

The case of farm dairies shows how a LAFS process can be generated in order to increase income opportunities in a remote rural area in Sweden. During the 1980's collective action was initiated with the purpose of saving goat farms, however the effects of this collective action goes far beyond what was expected. It led to the creation of an infrastructure that won national recognition and that since has supported the creation of countless small food artisan businesses over the entire country trough courses, providing a meeting point and incentives that promote quality, for example the National Championship of Artisan Food. But most important for the farm dairy sector, the institutional structure that eventually was created to change the "rules of the game", not the least by gaining recognition from the national food safety and health authorities.

Moreover, in the fists step of the SYAL process, the initiation of structural collective action led to the creation of an organization to modernize the trade. One spin-off effect was that at least two new partnerships around the re-creation and commercialization of traditional products were initiated around Vålåloffen and Cellar Stored Goat cheese. This proves that a virtuous circle was created as new processes of identification and qualification of local resources were initiated, when two traditional products were updated and rescued for the future.

Some of the traditional and territorial characteristics of dairying in Jämtland have been preserved and are reproduced by the farm dairy sector. Traditional products, landraces, and biodiversity are all embedded in the history and culture of Jämtland, but the new elements that have been inserted and adopted, especially the knowledge and know-how of foreign regions and foreign recipes have all added value to the SYAL process. These have contributed to awaken the interest for artisan cheese in young generations that thereby became a vehicle for the preservation of part of the cultural patrimony of Jämtland.

Very few consumers, $13 \%$, highlighted a link between farm dairy products and local tradition. Consumers were much more concerned with quality and maintaining a living rurality, which is a conclusion worth considering for the future

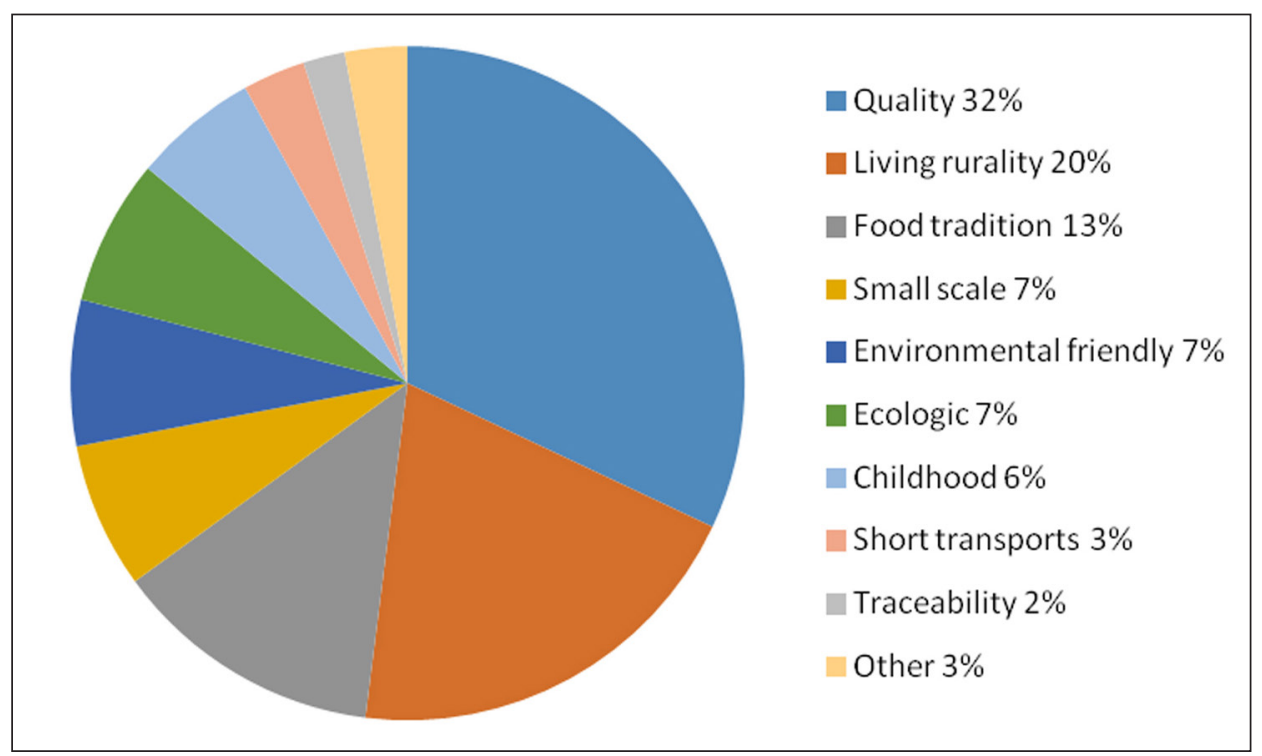

FIGURE 1. Attributes that consumers relate to the products. 
The lion's share of research emphasizes the importance of origin (products, inputs, recipes landraces, fodder, et cetera) in the creation of value within a LAFS. Often the creation of value is seen in relation to a geographical indication. In this sense, previous research in Europe at least is quite normative. But the case of farm dairies in Jämtland has clearly showed that this strictness and normativity is not always necessary. Foreign elements can be used to preserve and promote local resources and to create a number of values related to finance, culture and nature.

\section{NOTES}

1 This research has been conducted with the financial support of the Swedish Science Foundation, Vetenskapsrådet. The interviews and survey that are partly the base for the article were collected together with Dr. Madeleine Bonow, Södertörn University. I would like to thank the anonymous peer reviewers that helped with constructive comments on how to improve this paper.

2 The results of the articles have been gradually published in different articles, therefore only a part of the interviews have been used here.

3 Östersund is the capital of Jämtland and also the only city, with 200 thousand inhabitants.

4 Göran Henriksson was the Director of the regional dairy Milko's processing plant in Östersund. [Interviewed 12/October/ 2010].

5 Tätmjölk is produce by fermenting milk together with butterwork. This herb helps to thicken the milk, that gets a texture similar to yoghurt but with less acidity. For some reason, during lightning storms thick milk gets clushed, losing its texture.

6 Bodil Cornell is the General Director of Eldrimner. [Interviewed 23/June/2010, and a second time 8/May/2013].

7 Informant AK [Interviewed 27/June/2010]

8 Informant AK [ interviewed 27/June/2010].

9 Informant AK [ interviewed 27/June/2010].

10 Informant $\mathrm{MH}$ [interviewed 10/August/2012] and informant TO [interviewed 29/June/2010].

11 Swedish crowns. $450 \mathrm{scr}=48 €$. www.oanda.com [Accessed 13/ July/2015].

12 Informant AK [second inverview 11/January/2011].

13 Anna Berglund is the Education Manager at Eldrimner and she was also the project coordinator for "Söka Gammalt Skapa Nytt" project between 2004 and 2008. [Interview 24/June/2010]

14 Informant TO [Interviewed 29/June/2010).

15 Kjell Larsson made a plant inventory on behalf of the County Board Administration in the summer of 1990. The document is an internal working document and has thus not been published, but is a part of the public records of the Swedish state.

16 One of the farm dairies has only sheep, however these are not landrace sheep.

\section{REFERENCES}

Åquist, Ann-Cathrine (2002) Tidsgeografi - En introduktion. Örebro Universitet, Örebro, Sweden. http://web.abo.fi/fc/opu/ amne/geogr/Tidsgeografi_introduktion.pdf. [Accessed 12/ June/2015].

Arfini, Filippo; Mancini, Maria Cecilia and Donati, Michele (eds.) (2012) Local Agri-Food Systems in a Global World: Market, Social and Environmental Challenges. Cambridge Scholars Publishing, Newcastle upon Tyne, United Kingdom.

Åsling, Nils G. (1967) Näring I Omdaning, 150 år med Lantbruket och Hushållningssällskapet $i$ Jämtland och Härjedalen. ÖPE Tryck, Östersund, Sweden.

Barjolle, D.; Renard, O. and Bernardoni P. (eds.) (2013) Étude du potentiel de la commercialisation des produits agricoles des pays ACP (Afrique, Caraibes, Pacifique) utilisant les indications géographiques et les marques avec origine (ACP-AGGI). European Commission, Brussels. http://ec.europa.eu/agriculture/external-studies/2013/gis-acp-countries/fulltext fr.pdf.

Barjolle, D. and Sylvander B. (2000) Protected Designätions of Origin and Protected Geographical Indications in Europe: Regulation or Policy? Recommendations. European Commission, Brussels. http://www.origin-food.org/pdf/pdo-pgi.pdf. [Accessed 2/ September/2014]

Barraclough, Emma (2011) "Commission urged to encourage GIs". Managing Intellectual Property, 11 (15). http://www.managingip.com/Article/2935203/Commission-urged-to-encourageGIs.html [Accessed 17/June/2015].

Belletti, Giovanni and Marescotti, Andrea (2011) "Evaluation of Geographical Indications, a methodology". In The Effects of Protecting Geographical Indications Ways and Means of their Evaluation, edited by the Swiss Federal Institute of Intellectual Property. Bern, Switzerland.

Bérard, L. and Marchenay, Ph. (2007) "Localized products in France: Definition, protection and value-adding". Anthropology of Food. https://aof.revues.org/415. [Accessed 2/May/2015].

Berglund, Anna (2006) Källarlagrad getost. En rapport om traditionell getost I Jämtland/Härjedalen. Eldrimner, Östersund, Sweden.

Bonow, M and Rytkönen, P. (2013) "Small Scale Farm Dairies in Jämtland, Ancient Practices in Modern Forms". In The Return of Traditional Food, edited by Patricia Lysaght, Lund. Studies in Arts and Cultural Studies, Lund, Sweden: 81-93.

Boucher, F. and Pomeón, T. (2010) "Reflexiones en torno al enfoque SIAL: Evolución y avances desde la Agroindustria Rural (AIR) hasta los sistemas Agroalimentarios Localizados (SIAL)". Spatial Dynamics in Agri-food Systems: Implications for Sustainability and Consumer Welfare. EAAE Proceedings, Parma, Italy.

Bringéus, Nils-Arvid (1997) "Matkulturen i jämförande perspektiv i 1700-talets Norrland". In Maten meir enn föda, edited by Bö, Sigrid and Nordby, Guro. Arendala, Sweden.

Carlsson, B.; Edquist, C.; Eliasson, G.; Jacobsson, S. and Lindholm-Dahlstrand, A. (2000) Innovationssystem, kluster och kompetensblock: Fyra essäer om innovationer, tillväxt och sysselsättning. Rådet för Arbetslivsforskning (RALF) och Vinnova, Stockholm, Sweden.

Ciccone A. (2002) "Agglomeration effects in Europe". European Economic Review, 46 (2): 213-227.

Courlet C. (2008) L'Économie Territoriale. Presses Universitaires de Grenoble, Grenoble, France.

Davoudi, S.; Evans, N.; Governa, F.; Santangelo, M. (2008) "Territorial Governance in the Making". Approaches, Methodologies, Practices, 46: 33-52.

Deppeler A.; Stamm, H. and Thévenod-Mottet, E. (2011) "Why evaluate the effects of the protection of GIs?". In The Effects of Protecting Geographical Indications Ways and Means of their Evaluation, edited by the Swiss Federal Institute of Intellectual Property. Bern, Switzerland.

Eldrimner. (2014) Fäbodnäringens branschriktlinjer till god hygienpraxis vid fäbodar vid tillverkning av mjölkprodukter med traditionella metoder. Eldrimner, Östersund, Sweden.

Eriksson, Camilla (2013) Fäboden som politiskt rum. Sveriges lantbruksuniversitet, Acta Universitatis agriculturae Sueciae 25, Uppsala, Sweden.

Hansen, I.; Hansen, H.S.; Christiansen, F; Braastad, B. and Bakken, M. (2001) "Variation in behavioural responses of ewes towards predator-related stimuli". Applied Animal Behaviour Science, 70: 227-237. doi: 10.1016/S0168-1591(00)00155-6.

Hayes, D. J.; Lence, S.H. and Stoppa, A. (2004) "Farmer own brands?". Agribusiness, 20 (3): 269-285.

Head, K.; Ries, J. and Swenson, D. (2002) "Agglomeration benefits and location choice: Evidence from Japanese manufacturing investments in the United States". Journal of International Economics, 38 (3-4): 223-246.

Higgins, V.; Dibden, J. and Cocklin, C. (2008) "Building alternative agri-food networks: Certification, embeddedness and ag- 
ri-environmental governance". Journal of Rural Studies, 24: 15-27.

Ilbery, B and Kneafsey, M. (1999) "Niche markets and regional specialty foods in Europe: Towards a research agenda". Environment and Planning A, 31: 2207-2222.

Joslin, T. (2006) "The War on Terroir: Geographical Indications as a Transatlantic Trade Conflict". Journal of Agricultural Economics, 57 (3): 337-363.

Jordbruksverket (2003) Jordbruksstatistisk Arsbok. Jordbruksverket, Jönköping, Sweden.

Jordbruksverket (2013) Jordbruksstatistisk Arsbok. Jordbruksverket, Jönköping, Sweden.

Krugman, P. (1991) Geography and Trade. MIT Press, Cambridge and London.

Larsson, J. (2003) “Vad är en fäbod?”. Bebyggelsehistorisk tidskrift, 45.

Länsstyrelsen (2014) Rovdjur $i$ Jämtlands län. Länsstyrelsen. Östersund, Sweden. http://www.lansstyrelsen.se/jamtland/Sv/ djur-och-natur/rovdjur/Pages/default.aspx. [Accessed 26/February/2014].

McPherson, A. (1997) Våra forna bymejerier $i$ Jämtlands län. Länsstyrelsen i Jämtlands län, Östersund, Sweden.

Morgan, K.; Marsden, T. and Murdock, J. (2006) Worlds of food. Oxford University Press, Oxford, United Kingdom.

Muchnick, J. (2009) "Localized Agrifood Systems: concept development and diversity of situations". Proceedings of the Annual Meeting of the Agriculture, Food and Human Values Society and the Association for the Study of Food and Society. Pennsylvania State College, University Park, United States.

Porter, M. (2000) "Location, Competition, and Economic Development: Local Clusters in a Global Economy". Economic Development Quarterly, 14 (1):15-34.

Reviron, S.; Thevenod-Mottet, E. and El Benni, N. (2009) "Geographical indications: creation and distribution of economic value in developing countries". In Working Paper series 2009/14. Swiss National Centre of Competence in Research. NCCR Trade Regulation, Bern, Switzerland.

Requier-Desjardins, Denis (2007) "L'evolution du debat sur les SYAL: le regard d'un économiste". In Les dynamiques territoriales: Débats et enjeux des différentes approaches disciplinaires, XLIIIe Colloque de l'ASRDLF. Grenoble et Chambéry, France.

Ribeiro, J.C. and Santos, J.F. (2004) "Portuguese olive oil and the price of regional products: does designation of origin really matter?" NIPE WP3. Working Paper Series, Universidade do Minho, Braga, Portugal.
Rytkönen, Paulina and Gratzer, Karl (2012) “Geografiska Ursprungsbeteckningar, en preliminär reflektion”. Södertörn Working Papers 1, Flemingsberg, Sweden.

Rytkönen, Paulina; Bonow, Madeleine; Johansson, Magnus and Persson, Ylva (2013) "Goat cheese production in Jämtland - a pioneering experience in the re-emergence of local food". Acta Agriculturae Scandinavica, Section B - Soil \& Plant Science, 63 (1):38-46.

Rytkönen, Paulina; Bonow, Madeleine and Dinnétz, Patrik (2014) "Mountain Agriculture at the crossroads, biodiversity, culture, and modernization, conflicting and interacting interests". In Farming systems facing global challenges: Capacities and strategies, edited by Aenis, T.; Knierim, A.; Riecher, M.C.; Ridder, R.; Schobert, H. and Fischer, H. IFSA (European Farming Systems Association). Berlin, Germany. http://ifsa.boku.ac.at/ cms/index.php?id=134\&L=0. [Accessed 15/October/2014].

Sforzi, M. and Mancini, C. (2012) "The reinterpretation of the agrifood system and its spatial dynamics through the industrial district". Agricultural Economics, 11: 510-519.

SOU. (2006) Se landsbygden! Myter, sanningar och framtidsstrategier, Slutbetänkande av Landsbygdskommittén 2006/101. Statens Offentliga Utredningar, Stockholm, Sweden./.

Staffansson, J-Å. (1995) Svenskt Smör, produktion, konsumtion, utrikeshandel 1861-1913, (Lund). Lund University Press, Lund, Sweden.

Stryjan, Yohannan and Fröman, Eva (1991) Jämtspira - En studie I innovation. Sveriges Lantbruksuniversitet. Uppsala, Sweden.

Svedjeland, Knut (1964) Från bymejeri till storindustri, Jämtlands läns mejeriförening. Östersunds-Postens civiltryckeri, Östersund, Sweden.

Tunón, H.; Axelsson-Linkowski, W.; Bele, B.; Kvarnström, M.; Nordenhaug, A. and Wissman, J. (2013) "Views of landscape, reflections on the governance of Scandinavian transhumance". Baltic Worlds, IV (3-4): 53-60.

Van Ittersum, K.; Candel, M. J. J. M. and Meulenberg, M. T. G. (2003) "The influence of the image of a product's region of origin on product evaluation". Journal of Business Research, 56: 215-226.

Vandecandelaere, E.; Arfini, F.; Belletti, G. and Marescotti, A. (eds.) (2009) Linking peoples, places and products, A guide for promoting quality linked to geographical origin and sustainable geographical indications. FAO, Rome, Italy. http://redd.pro/ sites/default/files/dokumenta/Linking_people_places_and_ products.pdf. [Accessed 17/May/2015].

Von Friedrichs, Y. and Skoglund, W. (2011) "Gastronomi som kraft för regional utveckling". In Gastronomins (politiska) geografi, edited by Bonow, Madeleine and Rytkönen, Paulina. Årsboken Ymer, Motala, Sweden. 